\title{
Fate of recycled tyre granulate used on artificial turf
}

\author{
Anja J. Verschoor ${ }^{1 *}\left(0\right.$, Alex van Gelderen ${ }^{2}$ and Ulbert Hofstra ${ }^{3}$
}

\begin{abstract}
The production of granulates as infill for artificial turf is able to process $21 \%$ of the end-of-life tyres in Europe, approximately 600 million $\mathrm{kg}$ per year. In doing so it avoids an annual $\mathrm{CO}_{2}$ emission comparable with the amount that could be absorbed by around $30 \mathrm{~km}^{2}$ of forest. However, dispersal of rubber infill to the environment is perceived as a problem. An amount of 3000-5000 kg granulate per field per year is currently used as underpinning for a European proposal to ban rubber infill as part of the intended restriction on intentionally added microplastics in 2021. By reviewing grey research reports, we found out that the dispersal rates are based on the false assumption that the annual granulate demand for refilling is necessary because of granulate losses to the environment. However, it has been ignored that part of the refill is needed because the infill layer settles and becomes more dense (compaction) and that part of the lost infill is collected and reused on the fields. In combination with unawareness and improper piling of snow in the past, these are the causes of the high estimates of infill dispersal per year. This paper shows the current stateof-knowledge about ELT granulate dispersal and shows that approximately 600-1200 kg refill is required annually to compensate for compaction and for some infill waste on pavements and in drainage sinks. Recommended mitigation measures are containment through optimized field and drainage construction, suitable maintenance equipment and practices and good-housekeeping rules for players and groundkeepers and handling end-of-life pitches. If these recommendations are implemented, the emission of ELT granulates to the environment can be reduced to virtually zero.
\end{abstract}

Keywords: Rubber granulate, Dispersal, Maintenance, Emission, Duty-of-care

\section{Background}

As a consequence of population growth and wealth a huge amount of end-of-life products is waiting for secondary use, recycling of the contained materials or recovery of energy. End-of-life tyres (ELT) are such a product. One billion tyres reach the end of their useful lives worldwide every year [39]. Since in 2005 the European Landfill Directive [1] has put a ban on land-filling of ELT, new applications were needed that could absorb the used tyres. This challenge has resulted in $58 \%$ material recycling, 35\% energy recovery and 3\% use in civil engineering ([12], see Fig. 1).

Major destinations of ELT are rubber granulate and powders; they absorb $43 \%$ of the total ELT [12].

\footnotetext{
${ }^{*}$ Correspondence: verschoor@demilieutafel.nl

1 De Milieutafel, Soest, The Netherlands

Full list of author information is available at the end of the article
}

Granulates come in different size fractions. Depending on the size fraction, the granulates are used as filler in for instance asphalt $(0-1 \mathrm{~mm})$, as infill in sports fields $(1-2 \mathrm{~mm})$, rubber tiles $(2-4 \mathrm{~mm})$ and as an elastic layer beneath sports fields $(4-8 \mathrm{~mm})$. Approximately half of the granulates (21\% of total ELT) is used as infill on sports pitches [30]. ELT granulates contain approximately $46 \%$ polymers [21] comprising natural and synthetic rubber, and therefore they are classified as microplastics [19].

Plastic recycling in general and recycling of ELT are important goals of the European Union [13]. The recycling of ELT to rubber granulate prevents the mining of virgin resources (rubber, oil, metals). It has been estimated that the recycling of $1000 \mathrm{~kg}$ ELT avoids the emission of $838 \mathrm{~kg}$ carbon dioxide [25]. The annual recycling of $21 \%$ of the European ELT to rubber infill for sports fields thus leads to an avoided $\mathrm{CO}_{2}$ emission of

\section{Springer Open}

(c) The Author(s) 2021. This article is licensed under a Creative Commons Attribution 4.0 International License, which permits use, sharing, adaptation, distribution and reproduction in any medium or format, as long as you give appropriate credit to the original author(s) and the source, provide a link to the Creative Commons licence, and indicate if changes were made. The images or other third party material in this article are included in the article's Creative Commons licence, unless indicated otherwise in a credit line to the material. If material is not included in the article's Creative Commons licence and your intended use is not permitted by statutory regulation or exceeds the permitted use, you will need to obtain permission directly from the copyright holder. To view a copy of this licence, visit http://creativeco mmons.org/licenses/by/4.0/. 


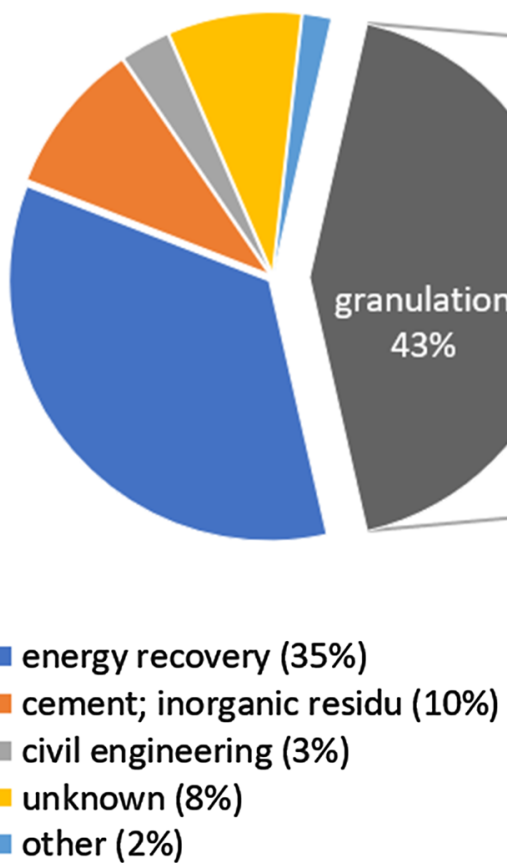

Fig. 1 Destinations of ELT in EU27 (+ UK, Serbia, Norway, Switzerland and Turkey), expressed as a percentage of the total collected mass of ELT. Total ELT released by these countries is 3.424 .500 tonnes; data 2017 [12]. * Other use of ELTs comprises use in steel mills and foundries (0.3\%) as well as use as dock fenders, blasting mats (1.2\%) pyrolysis (0.4\%). The material recycling in cement concerns the inorganic fraction of the tyres. ${ }^{* *}$ Energy recovery includes ELTs sent to cement kilns (29\%) as the energy fraction of co-processing ELTs in cement kilns and ELTs used in district heating/ power plants (6\%); ${ }^{* *}$ unknown also includes collected tyres waiting for treatment. Distribution over granulate fractions has been adopted from [30]

600 million $\mathrm{kg}$, which equals the amount that would be absorbed by approximately $30 \mathrm{~km}^{2}$ of forest per year [2].

ELT granulate appeared to be a suitable filler in sports floors, because it is elastic, durable and relatively cheap. The presence of affordable rubber infill enabled a rapid growth in the number of artificial turf pitches. ECHA estimated that there are more than 13,000 large synthetic turf fields in European Union (data 2017) and even a higher number of mini-pitches [34]. These pitches are mainly used for football. Compared to natural grass, these pitches allow year-round playing irrespective of the weather conditions. Because artificial turf tolerates intense playing, less fields and thus less land suffices to facilitate outdoor field sports.

However, despite of these positive characteristics the use of ELT, and plastics in general, is currently approached with criticism. Small fractions of plastics, the microplastics, are dispersed to the environment and enter the food-chain [27, 41], although the exposure and effects to humans seems to be very limited to date [33]. Because the rubber particles are heavier than water (specific density $\approx 1.16 \mathrm{~g} / \mathrm{cm}^{3}$ ), they tend to end up in soils and sediments. A common freshwater benthic organism (Gammarus pulex) has shown to ingest tyre-derived particles $(<500 \mu \mathrm{m})$, when offered in a laboratory setting
[31]. However, there were no significant effects on the growth and reproduction of G. pulex and three other types of aquatic benthic organisms up to a dosage of $10 \%$ tyre particles in the sediment.

To reverse the growing release of microplastics in the environment, the EU intends to adopt a restriction proposal on intentionally added microplastics, including ELT granulate, in 2021 [9]. ECHA's Risk Assessment Committee has proposed a total ban on the use of rubber granulate in artificial turf pitches, with a 6-year transition period [10]. However, an exception to this ban, provided that the dispersal of microplastics is kept below $7 \mathrm{~g} / \mathrm{m}^{2}$ (equivalent to approx. $40 \mathrm{~kg}$ on a pitch measuring $100 \times 60 \mathrm{~m}$ ), has been brought forward as an alternative option during the public consultations and the socio-economic assessment [11]. A policy decision that determines the future of rubber infill is expected in 2021 and will be taken by the European Commission and its member states.

In support of policy measures, the EU had conducted a study to quantify the most important sources of microplastics [18]. The study indicates that ELT granulate is a very small and local source, compared to other sources of microplastics such as tyre wear and paint, preproduction pellets and textile fibers. Besides these sources, 
fragmentation of plastic litter and cosmetics are more relevant than ELT granulate [28]. The quantities in these studies are not directly comparable because they focus on different environmental compartments and the geographical coverage is not identical, but overall it can be stated that ELT granulate comprises $<<1 \%$ of the microplastic emissions. The EU-study estimated, leaning on assumptions, a granulate dispersal of $1500-5000 \mathrm{~kg}$ per field per year. In their restriction proposal ECHA assumed that $10 \%$ of the refill, that is up to $500 \mathrm{~kg}$ per field per year ends up in the environment. Around the same time, new studies have been published that actually measured dispersal along different pathways [26, 32, 40]. The results enable adjustment and refinement of the existing estimates.

Besides polymers, tyre tread rubber contains approximately 19\% carbon black (filler), 19\% plasticizers and oils, and 16\% minerals, mostly silica, sulfur and zinc [21]. Previous human health concerns, based on the presence of heavy metals, polycyclic aromatic hydrocarbons and other organic substances in ELT granulate, have shown to be unnecessary. Several extensive risk assessments [8, $29,34])$, established that the chemical risk for humans, playing on artificial turf with ELT granulate, is negligible. However, ecosystems may be at risk because environmental quality criteria to protect ecosystems in soil have been exceeded for zinc, cobalt and mineral oil in several occasions [37]. In this paper, we focus on the emission of particles in view of the microplastics debate and do not address chemical issues again.

In order to prevent that a beneficial recycling option is discarded because of negative perceptions or worstcase assumptions, it is of the utmost importance that facts and figures about ELT granulate are made available. The research questions of this paper are: (1) what are the pathways, processes and factors that influence the amount of infill loss; (2) what is the variation of granulate dispersal from artificial turf fields to the environment; (3) what are the mitigation options? Information concerning these topics is currently scattered in several grey research reports that contain useful experimental data and measurements. Because some of the reports have been written in Dutch, Danish, Norwegian or Swedish, we translated the studies and included the essential details in this review in order to make the information accessible to a broader community.

\section{Dispersal processes and routes}

The distribution of granulates to the environment can be assessed in several ways, and both ways are represented in the literature:
1. Based on inquiries to the use of infill material, with subsequent assumptions about the dispersal routes. The uncertainty is high and depends on the extent and details of the sales inquiries, and about the assumed dispersal routes.

2. Based on actual measurements in the environment. The main uncertainty here is related to local variations in field construction, maintenance practices, field age, and weather conditions.

Emission of ELT granulate comes from unbound outdoor applications, mainly from football (soccer). During construction of soccer fields approximately 100-120 thousand $\mathrm{kg}$ ELT granulate is applied on the fields to support the synthetic grass fibers and to optimize playing conditions. In the use phase, periodical refills are necessary, because the thickness of the infill layer decreases over time, particularly on intensely agitated zones, such as the goal, penalty, corner and midpoint area.

The annual granulate refill is required to compensate for compaction and for losses (see Fig. 2). Studies that quantified these processes have been reviewed in the "Annual refill", "Compaction" and "Infill loss" section. Compaction of infill layers occurs through natural weathering by sunlight, through the presence of dirt and agitation by players and through gravitational force by [15]. Compaction and infill loss lead to a higher unsupported fiber length (free pile height) and deterioration of the field performance (such as vertical ball rebound, ball roll distance, rotational traction resistance, vertical deformation and force reduction [16]. Several maintenance methods are available to reverse the effects of compaction: drag brushing, also referred to as grooming (one to several times per week), powerbrushing (6-12 times per year), deep cleaning (once per 1 or 2 years), deep decompaction (once per 3 to 4 years) and rubber top-up when the infill layer becomes low. Also leaf blowing and snow clearance need to be done, depending on the season and local conditions. Rubber granulates can be dispersed to the environment during construction, maintenance and use of artificial turf fields. The amount of dispersed granulates depends on the construction of the fields, the methods and frequency of maintenance and awareness of constructors, caretakers and players.

Although dispersal of granulates to the environment can be prevented, this has unfortunately not been the case in the past two decades. Uncontrolled and mostly unintentional dispersal of granulates to soil and surface water might have occurred in the past decades when awareness about microplastics was not widespread. 


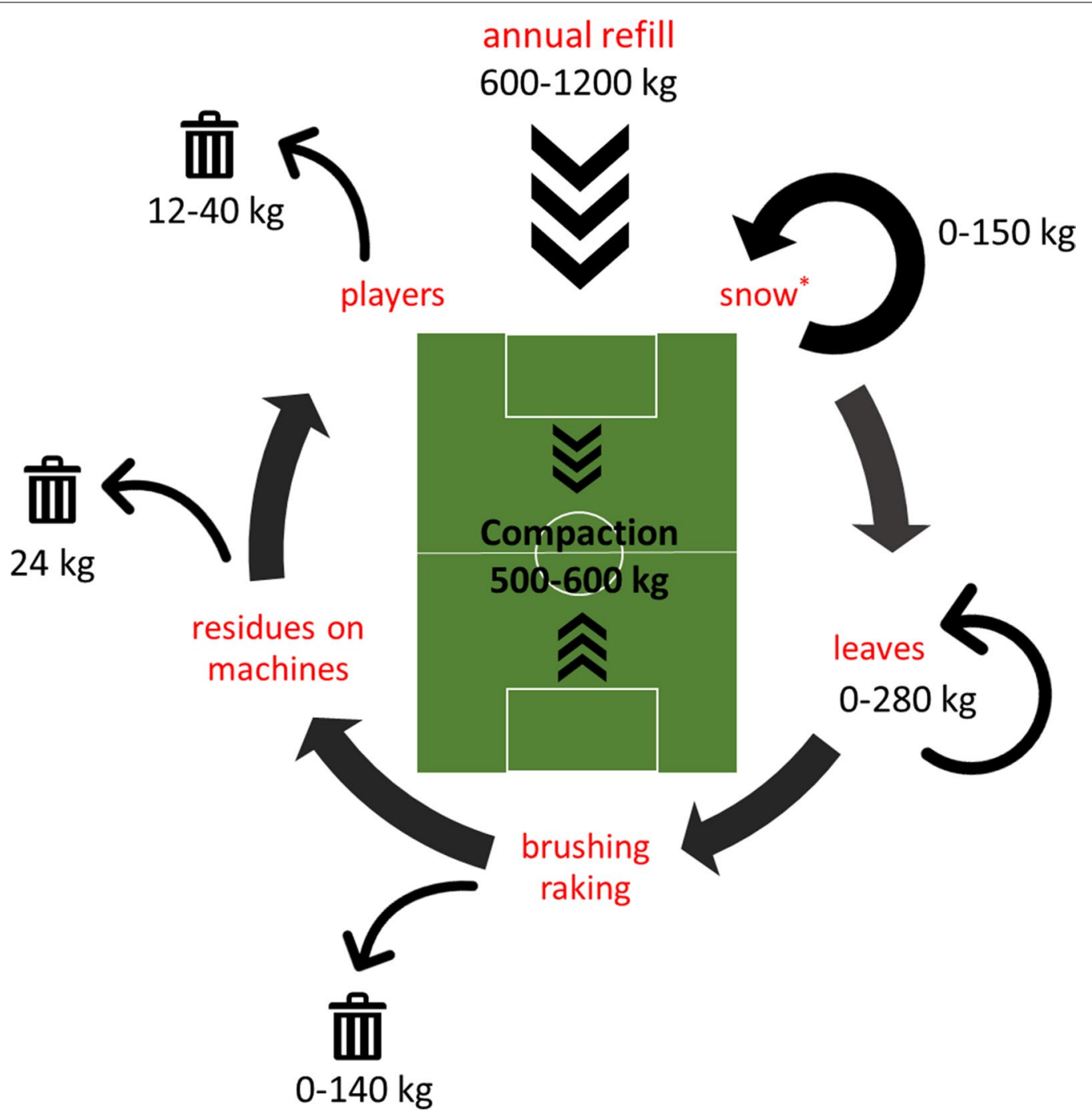

Fig. 2 Approximated annual input and output of ELT granulate on artificial turf. * Snow clearance is dependent on climate zone. Actual exact amounts depend on management and mitigation

\section{Annual refill}

The first estimates of environmental exposure were solely based on inquiries on the total annual use of ELT granulate. Early Scandinavian reports mention annual refill of 3000 to $5000 \mathrm{~kg}$ per year, which can be traced back to a recommendation of the Danish Football Union to guarantee optimal playing conditions [7]. The Danish recommendation of a refill of $3000-5000 \mathrm{~kg} /$ field/year is adopted by later studies [20, 22, 24] and in 2018 it formed the basis of an extrapolation to the European scale [18], which inspired ECHA to include ELT granulates in the restriction proposal from microplastics [9].

A study from Norway [36] assumed a refill of up to $12,000 \mathrm{~kg}$ per field per year for officially sized soccer pitches, based on an undocumented assumption of $10 \%$ loss of infill per year. A rationale for such a high amount has not been provided, although the Norwegian study adopted the Danish amount of 3000-5000 kg in the overall assessment, based on the fact that infill is also used on smaller pitches, such as playing grounds and school and kindergarten pitches. However, the previous recommendation of the Danish football association was meant for officially sized soccer fields and did not mention playgrounds. A Swedish study, based on inquiries at one football club, mentioned an amount of $3000-4000 \mathrm{~kg}$ granulate refill per year [38].

A later study estimates an annual refill of $2200 \mathrm{~kg} /$ field and seems to be based on more solid data, because more than 89 Danish clubs were asked about their infill 
use (Lindberg International, 2018 cited by [23]. A small inventory amongst three Dutch fields resulted in annual refill of 0,590 and $2200 \mathrm{~kg} /$ field [40]. The inventory is too small to derive a reliable average amount. Data from other countries were not found.

Refilling a whole field is seldomly done. In practice, caretakers mentioned that usually not the whole field needs refill, only certain intensively exposed zones, such as penalty and goal area $(16.5 \times 40.3 \mathrm{~m})$ and around the center mark $(9.15 \mathrm{~m} \phi)$. These areas account for approximately $1400 \mathrm{~m}^{2}$, equal to $20 \%$ of the total pitch area $(105 \times 68 \mathrm{~m})$ [14].

\section{Compaction}

Compaction can be measured in a laboratory under controlled conditions or in field set-ups where the results are more realistic, but may be influenced by the specific local weather conditions and field maintenance regime. Data are available from both type of experiments, which are described below.

\section{Laboratory measurements}

Laboratory testing has been conducted to investigate controlled density changes in the rubber infill simulating compaction due to pressure of players and decompaction by raking [15]. A $65 \mathrm{~mm}$ monofilament carpet $(0.5 \times 0.75 \mathrm{~m})$ was filled with sand $\left(13 \mathrm{~kg} / \mathrm{m}^{2}\right)$ and SBR rubber $\left(14 \mathrm{~kg} / \mathrm{m}^{2}\right.$, diameter $\left.0.5-2.5 \mathrm{~mm}\right)$. The sand layer was applied first and was conditioned with 50 cycles of a weighted studded roller $(40 \mathrm{~cm}$ wide and $43.6 \mathrm{~kg}$ ). The sand layer thickness was measured on 24 points, a deviation $\pm 1 \mathrm{~mm}$ was allowed. SBR granulate was added in portions of $2 \mathrm{~kg}$ batches with raking in between. The system was installed in triplicate; the compaction was tested after either 0,200 or 500 cycles of rolling with the weighted studded roller. One cycle was equal to two passes of the roller, one outward and one return. Measurements of the total infill depth were done on 3 points on the field, on midpoint and $15 \mathrm{~cm}$ distance apart towards the short edges.

During the experiment, the infill depth decreased from $31.0 \mathrm{~mm}$ in the beginning to $27.4 \mathrm{~mm}$ at 50 cycles and $22.4 \mathrm{~mm}$ at 500 cycles. These data imply a compaction of, respectively, 11 and $27 \%$. The study shows that compaction can be partly reversed by raking, also under field conditions. It is not clear how the cycles of the weighted studded roller can be translated to realistic outdoor conditions.

\section{Field measurements}

The compaction under outdoor conditions was determined on two football pitches in The Netherlands [40]. The first field (located in Hoogeveen, installed in 2007) was a well-maintained 11-year-old pitch where leaf blowing has always been done in an inward direction. The second field (located in Amsterdam, installed in 2008) was not well maintained, refill had not taken place for years and leaf blowing was done in an outward direction. Samples of the infill layer were taken in March 2017 on each pitch on the penalty spot and in the goal areas and on two reference points in the strip just outside the field markings. The spot dimensions were $30 \times 30 \mathrm{~cm}$, where all the loose material, including the sand, was recovered until the carpet was visible. The mass of the infill was determined undried. The results are shown in Table 1 section A.

A compaction of $8.5 \mathrm{~kg} / \mathrm{m}^{2}$ has occurred over a period of 11 years on the well maintained Hoogeveen field. This equals a compaction of $2.7 \%$ per year. This implies that an amount of $0.8 \mathrm{~kg} / \mathrm{m}^{2}$ per year was used to compensate for compaction in high-use areas.

A compaction of $2.7 \%$ per year was also found on the Amsterdam field. The total amount of recovered infill was only approximately $4 \mathrm{~kg} / \mathrm{m}^{2}$, which is very low, considering that a new field is constructed with an initial amount of $15 \mathrm{~kg}$ infill $/ \mathrm{m}^{2}$. This field is therefore considered to be not representative for current maintenance practices. An infill amount of only $4 \mathrm{~kg} / \mathrm{m}^{2}$ could imply that $11 \mathrm{~kg} / \mathrm{m}^{2}$ may have been disappeared to the surrounding environment, an amount that equals 78.5 thousand $\mathrm{kg}$ for this particular field $(\approx 8000 \mathrm{~kg} /$ year $)$ in the past $9-10$ years. Poor maintenance practices, in particular leaf blowing in outward direction, which unintentionally also transports granulate off-field, may be responsible for this loss.

If we adopt compaction rates of $2.7 \%$ per year from the abovementioned studies and an initial infill amount of $100-120$ thousand $\mathrm{kg}$, this would imply that approximately 500-600 kg ELT granulate is needed to compensate compaction.

\section{Infill loss}

\section{Dispersal by players}

Three studies are available that describe results of measurements to ELT granulates in shoes and socks.

A first study was a citizen science project in 2017 in Norway, where 12,591 participating school children collected data about infill loss through shoes and clothing [26]. A number of 286 schools of 144 municipalities studied 592 soccer matches on 343 soccer fields, 99\% were outdoor fields, $70 \%$ of the fields were regular 11-player pitches. The students were asked to play a football match of $2 \times 15 \mathrm{~min}$ and to collect granulate from shoes and clothing on a large white sheet. They recorded volume of the infill and infill type, field size, playing duration, number of players per match, the weather conditions as well as the type of environment at $10 \mathrm{~m}$ distance from 
Table 1 Measurements of the fate of ELT infill on three Dutch fields [40]

\begin{tabular}{|c|c|c|c|}
\hline & Rotterdam & Amsterdam & Hoogeveen \\
\hline \multicolumn{4}{|l|}{ General information } \\
\hline Year of construction & $8-2016$ & 2008 & 2007 \\
\hline Research period & Winter 2017-2018 & & \\
\hline Field age (years) & 1 & 10 & 11 \\
\hline Maintenance & $n$ & Poor & Well \\
\hline Leaf-blowing direction & Not described & Outwards & Inwards \\
\hline Sides with trees & 2 & 3 & 2 \\
\hline A. Infill compaction (\% per year) & & 2.8 & 2.7 \\
\hline Infill recovered from high-use areas $\left(\mathrm{kg} / \mathrm{m}^{2}\right)$ & & 4.3 & 31.4 \\
\hline Infill recovered from low-use area $\left(\mathrm{kg} / \mathrm{m}^{2)}\right.$ & & 3.1 & 22.9 \\
\hline Net compaction $\left(\mathrm{kg} / \mathrm{m}^{2}\right)$ & & 1.2 & 8.5 \\
\hline B. Infill loss in brushing waste (kg/field/year) & $21-140$ & $9-60$ & 0 \\
\hline Number of brushing events/year & 7 & 1 & 0 \\
\hline Amount of collected waste $(L)$ & $80 \pm 20$ & $240 \pm 60$ & 0 \\
\hline Infill content in brushing waste (\%v/v) & 7.6 & 50 & n.d \\
\hline Density of infill (kg/L) & 0.5 & n.d & 0.6 \\
\hline $65 \%$ as suspended mass (kg/field/year) & 1.0 & n.d & 1.1 \\
\hline C. Infill loss to pavement (kg/field/year) & 1.2 & 60 & 16 \\
\hline Total paved surface $\left(\mathrm{m}^{2}\right)$ & 1258 & 310 & 522 \\
\hline Time since last brushing (weeks) & 14 & 4 & 1 \\
\hline Mean infill $\left(\mathrm{g} / \mathrm{m}^{2}\right)$ & 0.8 & 38 & 2.2 \\
\hline Weekly spread (g/m²/week) & 0.1 & 10 & 2.2 \\
\hline Leafblowing (weeks per year) & & 13 & \\
\hline Dispersal by other means (weeks per year) & & 40 & \\
\hline $90 \%$ by leaf blowing (kg/field/year) & 0.8 & 44 & 12 \\
\hline $10 \%$ by other means ( $\mathrm{kg} /$ field/year) & 0.3 & 15 & 4 \\
\hline \multicolumn{4}{|l|}{ D. Infill loss to drainage sinks } \\
\hline Number of sinks & 8 & 0 & 20 \\
\hline Time since last cleaning (years) & 3 & - & 10 \\
\hline Mass flux to sludge (kg/field/year) & 1.5 & - & 1.7 \\
\hline E. Infill to ditches (kg/field/year) & & 4.3 & 6.1 \\
\hline Distance to ditch (m) & No ditch & 3 & 4 \\
\hline Thickness of sediment layer (m) & & 0.1 & 0.05 \\
\hline Width of ditch (m) & & 1.5 & 0.5 \\
\hline Length of ditch (m) & & 64 & 100 \\
\hline Time since last dredging & & 3 & 10 \\
\hline$\%$ infill in sediment & & 0.26 & 4.9 \\
\hline F. Infill to grass strip (kg/field/year) & 256 & 269 & 279 \\
\hline Infill concentration in sod (0-0.02 depth) $\mathrm{g} / \mathrm{kg}$ soil & $28-70$ & $190-220$ & $250-610$ \\
\hline Infill concentration in soil (0.02-0.05 depth) g/kg soil & $<0.1$ & 130 & $90-200$ \\
\hline
\end{tabular}

Assumptions are italic

the field. During the experiment, only $14 \%$ of the players wore football shoes (the others wore regular shoes). Before computing average infill loss, the outliers were removed.

On more than $81 \%$ of the fields the type of infill was ELT granulate (see Fig. 3a); other types of infill were EPDM, TPE, sand and organic infill. The humidity of the pitch appears to have a major impact on the amount of rubber granules that stick to the players. If the pitch is wet, more than twice as much granules will stick to shoes and clothes than if it is dry (Fig. 3b). On 11-player pitches under dry conditions an average of $0.6 \mathrm{~g}$ granulate per player was collected (in 187 

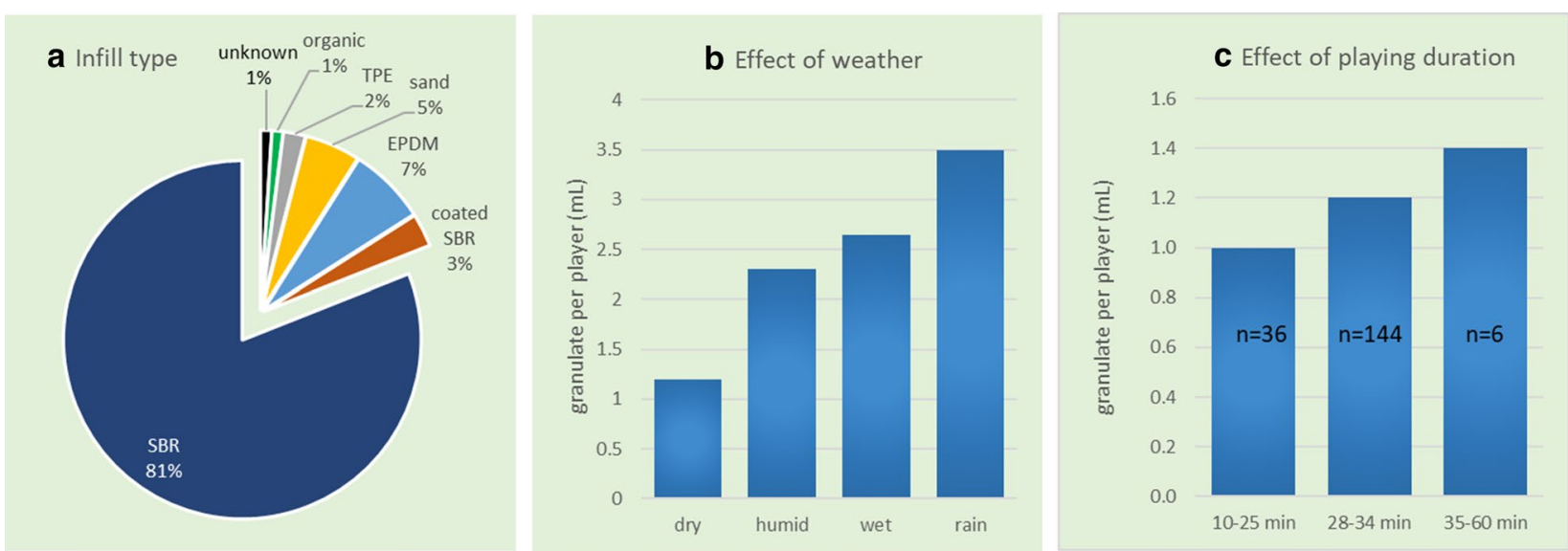

Fig. 3 Norwegian Citizen science project on infill loss via players shoes and clothing (data: [26]). a Percentage of fields with certain infill types; b effect of weather on the amount of collected granulate on 11-player pitches; $C$. effect of playing duration on the amount of collected granulate during dry weather

matches) and under wet conditions (damp, wet field or during rain) $1.35 \mathrm{~g}$ per player was collected (in 192 matches).

The actual playing duration varied from 10 to $100 \mathrm{~min}$ per match, on average $29.3 \mathrm{~min}$. The data were grouped in three time intervals to investigate if the amount of collected particles is related to the playing duration. It seemed that the amount of rubber increased slightly with the length played (Fig. 3c).

In a second case study, in Kalmar in Sweden in 2019, the amount of granulate that has clung to shoes and socks of players has been quantified through weighing [32]. After a playing duration of 60-120 min (average $93 \mathrm{~min}$ ), players and coaches from various football teams had to brush off clothes and shoes, and also empty their shoes, in a special tub. The total number of players included in the survey was 376 (an average of 16 per occasion). Measurements were taken on 23 occasions during the period Oct 2018-Apr 2019. In this study, the weather conditions have also been taken in to account. Under wet conditions significantly more granulate was collected than under dry conditions (onesided $t$-test, $p=0.02)$. Median amounts of collected granulate was $0.7 \mathrm{~g} /$ player/occasion under dry conditions $(n=12)$ and $2.2 \mathrm{~g} /$ player/occasion under wet conditions $(n=12)$. The overall mean under all weather conditions is $1.5 \mathrm{~g} /$ player/occasion.

A third study investigated the amount of granulate on shoes and socks of one 90-min match during dry weather conditions in The Netherlands [40]. After the match, players walked about $200 \mathrm{~m}$ to the dressing rooms, were they handed over socks and shoes to the

Table 2 Estimation of infill loss by clinging to shoes, socks and clothes determined in three studies

\begin{tabular}{|c|c|c|c|c|c|c|}
\hline \multirow[t]{2}{*}{ Country } & \multicolumn{3}{|c|}{$\begin{array}{l}\text { Amount of granulate clung to socks/shoes } \\
\text { (gram per person) }\end{array}$} & \multirow[t]{2}{*}{$\begin{array}{l}\text { Playing duration } \\
\text { (minutes) }\end{array}$} & \multirow[t]{2}{*}{ N players tested } & \multirow[t]{2}{*}{$\begin{array}{l}\text { Loss per field } \\
\text { per year }(\mathrm{kg})\end{array}$} \\
\hline & Dry & Wet & Mean & & & \\
\hline Norway ${ }^{a}$ & 0.54 & 1.6 & 1.1 & 29 & 12,591 & $40^{\mathrm{a}}$ \\
\hline Sweden ${ }^{b}$ & 1.1 & 2.5 & 1.7 & 93 & 645 & $26.8^{b}$ \\
\hline The Netherlands ${ }^{c}$ & 0.9 & - & & 90 & 11 & $12^{c}$ \\
\hline
\end{tabular}

\footnotetext{
a $[26]$

$0.88 \mathrm{~g}$ per player $\times 22$ players per field $\times 2200 \mathrm{~h}$ (occasions) per year

Bulk density of ELT rubber $=0.45 \mathrm{~g} / \mathrm{mL}$

b [32]

$1.66 \mathrm{~g}$ per player $\times 21$ million players $/ 1300$ fields per year

c [40]

$0.9 \mathrm{~g}$ per player $\times 321$ players per field per week $\times 40$ weeks per year
} 
researchers, who quantified the amount of granulate by weight. This single observation resulted in an average amount of $10 \mathrm{~g}$ for the whole team. Assuming 11 players, this accounts for $0.9 \mathrm{~g}$ per player.

In Table 2, the infill losses by shoes and clothing determined in the 3 investigations are compared. Although the Norwegian study is by far the most extensive study, the average test playing duration was only $29 \mathrm{~min}$. The Dutch study only concerned one occasion. Therefore, the Swedish mean value of $1.5 \mathrm{~g}$ per player is the most representative value for regular $90-\mathrm{min}$ matches.

The estimated amount per field in the reports varied between 12 and $40 \mathrm{~kg}$ per field per year. Each study applied different extrapolation methods to assess the total loss per field, and the assumptions and actual situation vary between countries. Based on the data in Table 3 and the given fraction of wet and dry days in each countries, estimates can be made for countries in different climate zones.

\section{Dispersal by maintenance Brushing waste}

Brushing is done to level the field. Infill loss in brushing waste has been determined in the Netherlands in 3 fields with ELT infill [40]. The amount of dirt and the granulate content in the dirt was determined in 2 ways: (1) based on interviews with caretakers and (2) based on measurements after density separation of samples. In Table 1 section $\mathrm{B}$, the field characteristics and results are summarized. The amount of dirt was between 1 and 3 wheelbarrows per occasion (one wheelbarrow has a volume of $80 \pm 20 \mathrm{~L}$ ). The measured infill content in a sample from a field with ELT granulate was $7.8 \% \mathrm{v} / \mathrm{v}(3.8 \% \mathrm{~m} / \mathrm{m})$. However, one caretaker mentioned that the content of ELT granulate can be as high as $50 \%$, which was demonstrated by photographs.

It appeared that the actual brushing frequency of $0-7$ times per year is lower than the recommended frequency of once in 1 or 2 weeks. The annual rubber infill collected by brushing is estimated to be between 0 and $140 \mathrm{~kg}$ per field per year. Dispersal to the environment by brushing can be minimized if the residue is disposed of as waste.

Table 3 Granulate (gram) removed from a maintenance machine after employment on wet and dry field [32]

\begin{tabular}{llr}
\hline Field conditions & \multicolumn{2}{l}{ Cleaning method } \\
\cline { 2 - 3 } & Brushing and blowing & Blowing only \\
\hline Dry & $1775(n=1)$ & $15 \mathrm{~g}(n=3)$ \\
Wet & $5100(n=1)$ & $1765(n=2)$ \\
\hline
\end{tabular}

$[26,32,40]$

\section{Snow clearance}

Snow clearance is commonly done in Nordic countries. Snow blowers, snow brushers or snow ploughs can be used. Which one is most suitable depends on the snow conditions. If snow is unlawfully dumped on adjacent soil or ditches, significant amounts of granulate could end up in the natural environment. Moreover, snow clearance with losses of infill is also a financial burden to communities, as new infill needs to be purchased for top-up. Increased awareness about microplastics dispersal had led to better instructions and development of new machineries that remove snow and leave or return the granulate on the field.

The amount and frequency of snow clearance and the infill that comes along with it vary enormously from one field to another, depending on the climate conditions and on the intensity of maintenance and the way the snow is stored. A Swedish study [38] estimated that every time when snow is removed using a snow plough, approx. 20-30 L of infill is removed. The study is based on interviews with caretakers for artificial turf fields in different Swedish local communities. Assuming 10 snow removals per year and a bulk density of $0.5 \mathrm{~L} / \mathrm{kg}, 100-150 \mathrm{~kg} /$ year ELT granulate is removed from the field during snow clearance. This amount can be reused on the fields once the snow has melted, if the snow is properly piled.

It can be noted that also within the Nordic region, the need for snow clearance is highly variable. Maintenance of artificial turf fields in Norway is a very important factor in relation to the spread of microplastics in the form of infill material, especially in the winter [3]. Whether the fields are located in the cold or the warm part of Norway is of considerable importance. The fields close to the coast receive the least snowfall and lost the least infill, whilst the northerly, inland fields lost granulate due to snow clearance. Four coastal field were studied which have been in operation for 10 years, and still weighed exactly the same when recycled as when they were new, while infill was never added. The amount of infill additionally used on fields in relatively warm, coastal areas is therefore low. The cold, northerly fields need 10-20 times more infill added as a result of snow clearance. Both studies indicate that weather conditions are of importance for the dispersal of infill. However, the maintenance practices are the decisive factor.

\section{Leaf blowing}

To our best knowledge, no studies are available about the effect of leaf blowing on the dispersal of ELT granulate. Nor are there reports available about transport of rubber granulate by wind. Because of the size and specific density $\left(1.16 \mathrm{~kg} / \mathrm{m}^{3}\right)$ of rubber particles, transport by wind is unlikely. 
There are several types of equipment with large differences in the potential spread of rubber granulate. Leaves and dirt can be removed by sweeping and picking up by hand, by leaf blowers or by several types of power brushes and vacuum cleaners. For example, a simple hand-held leaf blower, when applied in an outward direction, is powerful enough to spread leaves and granulate to the grass strips adjacent to the fields. Blowing in an outward direction, where leaves were left to decompose outside the field, used to be an efficient way to clean the field. Currently, more modern equipment is on the market to sieve the leaves and granulate mixture that is collected during operation. In this way almost all of the granulate is reused on the field. An unknown amount of granulate remains in the collected mixture, which should be disposed of as waste and not be composted.

\section{Cleaning of equipment}

Granulate may be spread as well when maintenance equipment is cleaned by brushing or by high pressures water streams. A Swedish study determined how much granulate is released during cleaning of brushing maintenance equipment [32]. The study did not describe the exact type, brand or model of the equipment. The equipment was used on several occasions during dry and during wet field conditions; afterwards the machines were cleaned. Cleaning of the machines with compressed air with and without prior brushing was compared. The results are shown in Table 3.

It appeared that brushing was very effective in removal of granulate from the machines; on average $>6$ times more granulate was removed by a combination of brushing and air blowing than by air blowing alone. When fields were wet more granulate (>factor 3) stuck to the equipment, which is visible in the higher amounts removed from the machines. For the extrapolation of an occasional to an annual loss by the equipment, the author assumed 70 brushing maintenance occasions per year under $50 \%$ dry/wet conditions, and $10 \%$ release from the equipment during off-field time. During off-field time, granules that stuck to brushes, the wheels or the machine can be washed away by rain, blown away by wind or can fall from the machine through vibrations. The resulting potential total loss of granulates by a maintenance vehicle is approximately $24 \mathrm{~kg} /$ field/year.

\section{Environmental concentrations}

\section{Paved surfaces}

The spread of infill to paved surfaces can be caused by dragging along granulates with shoes or maintenance machines, but according to Weijer et al. [40], the major cause (in The Netherlands) is leaf blowing. In Nordic countries it can also be caused when snow clearance is deposited on paved surface.

In The Netherlands, the amount of infill on paved surfaces has been determined near 3 artificial turf pitches with ELT infill. The selected fields did not have precautionary measures in place, such as boardings along the sides. The spread of granulates to pavement has therefore not been prevented. Repeated observation plots of $1 \mathrm{~m}^{2}$ were marked on paved surfaces at $20 \mathrm{~m}$ distance from each other at the north, south, east and west side of the fields, implying that 12 observations were taken per field. The amount of infill was determined by visual comparison with reference plots with known amounts of infill. The results are summarized in Table 1 section $C$. The measured amount of infill spread to paved surfaces varied from 0.01 to $2.9 \mathrm{~kg} / \mathrm{m}^{2} /$ week (mean 0.4 , median $0.2 \mathrm{~kg}$ per $\mathrm{m}^{2}$ per week), which equates to 1 to $60 \mathrm{~kg}$ lost per pitch per year. The variation in the amount of infill found on paved surfaces is high, and there is no statistically significant effect of the geographic orientation. The highest amounts have been found on pavements in Amsterdam. This may be caused by the fact that there are more trees surrounding the pitch (so the need for leaf blowing is higher) than on the other locations (trees on 3 versus 2 sides of the field) in combination with an outwards blowing direction.

In the same study, the amount of infill in cattle grids and walk-in mats was determined and equated on average $11 \mathrm{~kg}$ per mat $(n=10)$.

\section{Drainage system}

Through stormwater run-off granulate that has not been swept from the pavement, can end up in the drainage system. The amount of granulate that is captured in drainage sinks will depend largely on the infrastructure around the pitches (boarding, cattle grid), on the maintenance equipment and on the awareness of caretakers and players. Two studies attempted to quantify the mass of infill that could end up in drainage sinks.

In the first study [40], sludge in 28 drainage sinks in the vicinity of 2 artificial turf pitches was sampled in January/February 2018. The amount of infill in the sludge was determined by a combination of visual inspection, sieving, washing, drying and weighing. In Rotterdam (field was 1.5 years old), eight sinks that were cleaned yearly, contained 62 g rubber granulate per sink. In Hoogeveen (field was 11 years old), 20 sinks contained on average $341 \mathrm{~g}$ rubber infill each. According to the caretaker, the sinks have never been cleaned before. Based on these two fields the maximum loss of infill to the drainage system is $2 \mathrm{~kg}$ per field per year (see Table 1 section D).

In the second study [32], stormwater traps and collecting wells were installed at a new football pitch with ELT 
infill in Sweden (constructed in September 2018). The field was surrounded by boarding to prevent spread of infill, special lining to pile up snow on the pitch and filters of respectively 100 and $200 \mu \mathrm{m}$ to collect microplastics in, respectively, the drainage system and stormwater traps. The traps were installed beneath the field, in the pavement surrounding the field to collect stormwater, in collection wells and in the drainage system of an asphalt road (for comparison). Traps were sampled at 7-8 occasions for up to one year after construction. The samples were analyzed on 5 plastic categories: (1) PP, PE, PS; (2) PMMA, PUR, PE; (3) rubbery particles (with silicon); (4) particle with chlorine, such as PVC; (5) particles with fluorine such as PTFE. Microplastics have been identified with the analysis methods SEM-EDX and FTIR. The method was able to detect microplastics $>10 \mu \mathrm{m}$. The analytical method was not able to specify ELT rubber specifically, but these are included in the category "particles containing silicon". The results are shown in Fig. 4.

Run-off from pavement was the major dispersal route with $15.5 \mathrm{~kg}$ microplastics per field per year. The amount of rubbery compounds in the stormwater was $26 \%$ containing, maximally 4-5 kg ELT granulate per field per year. This seems a relatively high amount, compared with the $1 \mathrm{~kg}$ mentioned above [40]. The study of Weijer concerned older fields and there were no filters installed in the drainage wells, so particles might have been moved further downstream in ditch sediment (see "Sediment"

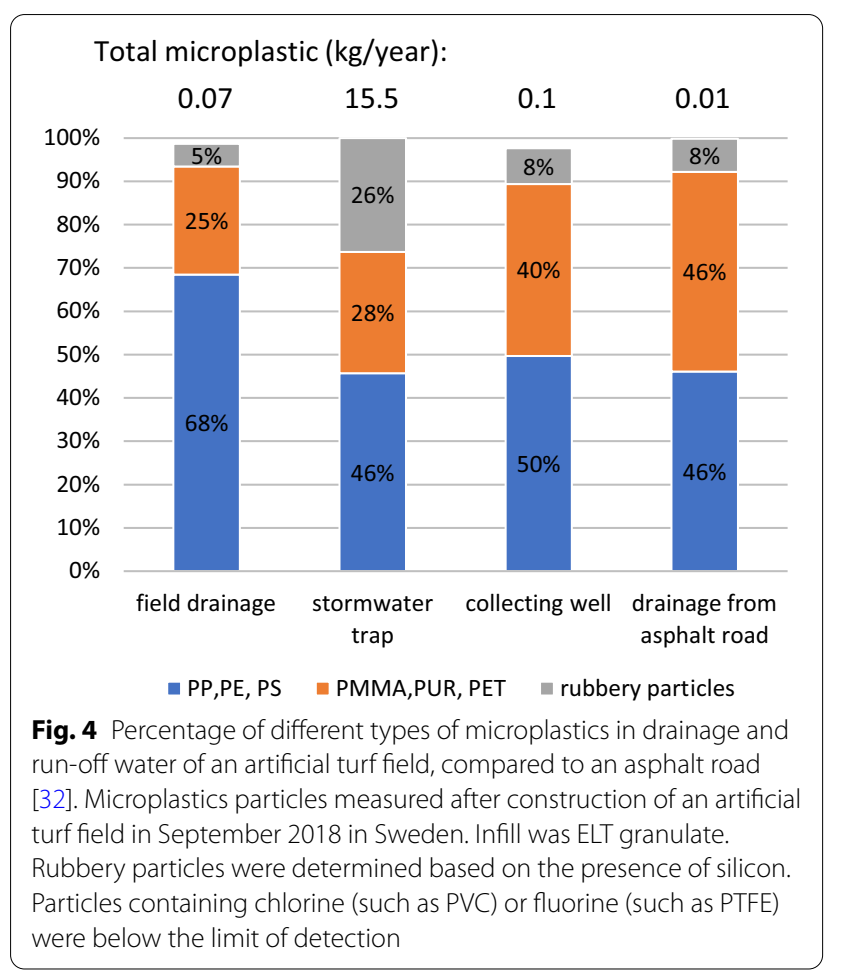

section). The stormwater traps in the study of Regnell [32] seem an effective mitigation measure, because further downstream, in the collection wells, the percentage of rubbery compounds is similar to the background of road run-off. It is striking, that even so close to the artificial turf, rubber granulate is a minor component in the overall microplastic mixture.

\section{Sediment}

Granulates can enter the ditches through the drainage system, surface run-off or improper leaf-blowing and snow clearance. Two Dutch studies describe measurements of rubber granulate in ditch sediment. ELT granulate are hydrophobic and heavier than water and as a consequence it will precipitate close to the discharge point. However, it is common practice that ditches are cleared from precipitated debris and dead plant materials periodically. Information about this practice is necessary to interpret the measurements.

In the first study [40], the ditches are only 3-4 m away from the 2 artificial turfs under investigation. A mixed sample was composed from 10 sediment sub-samples from ditches adjacent to the field. Sediment contained, respectively, $0.26 \% \mathrm{v} / \mathrm{v}$ of ELT granulate in the Amsterdam ditch, and $4.9 \% \mathrm{v} / \mathrm{v}$ in the Hoogeveen ditch (see Table 1 section E). Considering previous dredging and the ditch dimensions, the annual loss of infill from the artificial turf to the ditch is estimated $4-6 \mathrm{~kg}$ infill per field per year. This amount is approximately equal to the amount found by Regnell [32] in the drainage traps (see "Drainage system" section).

In the second study [37], the distance from the ditches to the artificial turf fields varied from 8 to $72 \mathrm{~m}$. Fields constructed between 1990 and 2009, containing ELT infill, were selected from 10 different municipalities. The ditches contained on average $0.22(0-2.8)$ g ELT granulate per $\mathrm{kg}$ dry sediment. The granulate concentrations are in the same order of magnitude as the lowest value measured by Weijer et al. [40]. Information about the time lapse since last dredging is incomplete.

\section{Soil}

Two studies in The Netherlands have sampled (independently from each other) with a grass plot sampler the topsoil around artificial turf football pitches for analysis of the rubber granulate content. The granulate content was based on a gravimetric separation of granulate and soil particles and is described in more detail in the Additional file 1 . The sampling positions relative to the artificial turf field of both studies are indicated in Fig. 5 .

In the study of Verschoor et al. [37], 20 samples were taken of the upper $10 \mathrm{~cm}$ of the grass strip surrounding the artificial turf. Samples were taken every $10 \mathrm{~cm}$ at a 


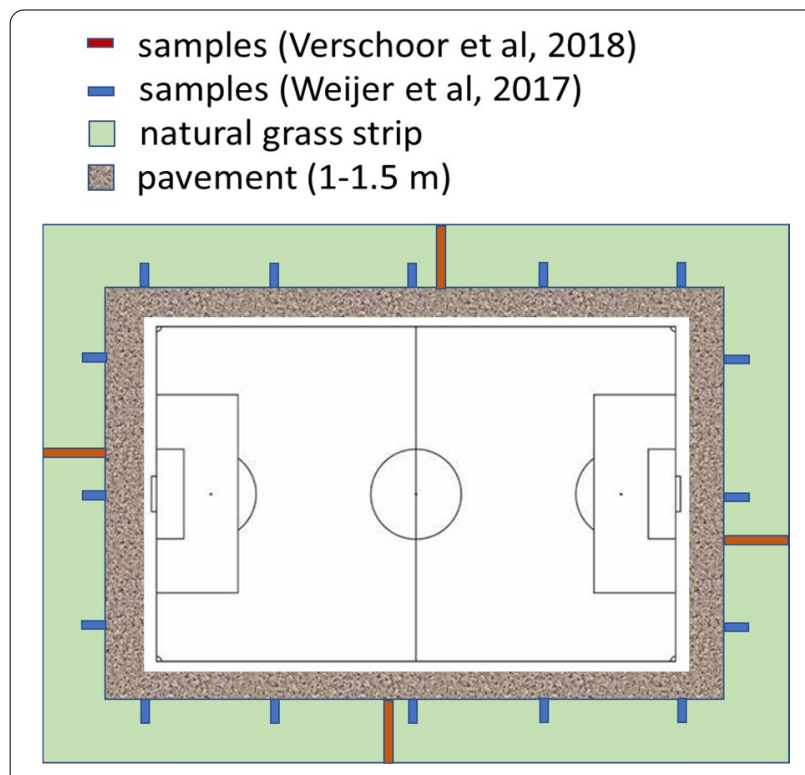

Fig. 5 Sampling scheme of soil in grass strips surrounding the artificial turf fields

distance of $0-2 \mathrm{~m}$ from the pavement. A median rubber infill concentration of $13 \mathrm{~g} / \mathrm{kg}$ soil (range 1-35 g/ $/ \mathrm{kg}$ ) in the upper $10 \mathrm{~cm}$ at a distance of $0-2 \mathrm{~m}$ from the field was determined in 10 fields of approximately 10 years old [37].

In the study of Weijer et al. [40] three sports field were investigated, one in Amsterdam and one in Rotterdam and one in Hoogeveen. The grass sod (upper $2 \mathrm{~cm}$ ) and the $5 \mathrm{~cm}$ beneath the grass sod were sampled separately to gain insight in the vertical distribution of the granulate. Samples were taken over a perpendicular line of 0-0.5 $\mathrm{m}$ distance from the surrounding pavement at every $20 \mathrm{~m}$ on each side of the field and combined and mixed into one homogeneous samples per side. Quantification and tentative identification have been done with a gravimetric method. The results are shown in Table 1 section $\mathrm{F}$.

From the findings in sod and subsoil in Rotterdam it can be deduced that $97 \%$ of the infill that has spread to the surrounding soil, was found in the sod of $2 \mathrm{~cm}$ thick. Only $3 \%$ was found in the $5-\mathrm{cm}$ layer underneath. However, this was in a new field; soil processes and organisms have had only half a year to spread the infill vertically. In Hoogeveen, on the other hand, $78 \%$ of the infill was found in the subsoil and 23\% in the sod. Construction works in 2006 over a longer period of time caused mixing and homogenization granulate over a thicker soil layers. The same might have happened in Amsterdam in 2007. Since 2010 the awareness has grown that dispersal of granulate needs to be limited as much as possible, also during the construction phase.

Granulate concentrations in the study of Verschoor et al. [37] are lower than in the study of Weijer et al. [40]. The difference is most likely caused by the larger strip $(0-2 \mathrm{~m}$ versus $0-0.5 \mathrm{~m})$ and the thicker layer $(0-10 \mathrm{~cm}$ versus $0-7 \mathrm{~cm}$ ) that has been sampled in the respective studies.

\section{Mass balance}

The principle of circular economy is that materials can endlessly be reused and recycled. Losses to the environment are undesirable. Loss to the environment has been perceived as one or the most important reason for refill [18]. It is difficult to derive general values for the amount of environmental loss, because it depends on the housekeeping rules, on behavior of players and caretakers, on available maintenance equipment and on infrastructure. On top of that, wet weather and especially snowy conditions may accelerate the dispersal of infill.

In Fig. 2 the material cycle of ELT granulate on artificial turf is drawn. Improper snow piling is potentially the most important reason for granulate loss from the field. However, large parts of Europe have a temperate or warm climate, where snow clearance is not an issue. It is probably not a coincidence that most of the studies to the fate of rubber infill have been conducted in Scandinavian countries, because of the high visibility of granulate in melting snow piles near the sport premise. It was assumed that up to 100-150 kg of ELT granulate per field per year could be lost due to snow clearance (see "Snow clearance" section). A way of preventing large-scale loss is better control of snow clearance [3]. With the right measures and procedures, the ELT that remains after the snow has melted, can be reused on the field.

When snow clearance is done on the whole field, refill is needed for the whole pitch $\left(7140 \mathrm{~m}^{2}\right)$. In countries where snow clearance is not needed, only locally wornout high-usage areas need refill. So in contrast to wholefield refill, in temperate zones it is likely that only local hot-spots are treated with additional infill, which requires lower amounts of granulate.

Based on the literature review we estimate that approximately $600-1200 \mathrm{~kg}$ infill per field is needed annually. Although there are examples of sports fields that never received refill. Under good and responsible management practices, environmental dispersal can be avoided. The most important reason for annual refill of artificial turf fields is compaction $(500-600 \mathrm{~kg})$. During compaction, no dispersion of infill to the environment occurs. The remaining part could be collected from pavements and drainage sinks and disposed of as waste (see Fig. 2). 


\section{Mitigation}

Not all the losses of ELT infill necessarily end up in the environment. There are many options to mitigate the dispersal of granulates to the environment. With current awareness on microplastic contamination, new protocols have been developed. The European Committee for Standardization has recently published guidance on how to minimize infill dispersion into the environment [6]. The guidance pays attention to the field design, installation, maintenance with special attention for snow clearance, changing rooms, retrofitting and the end-of-life stage of the artificial turf. Guidance is also offered by producers of infill materials [17] or field contractors [5].

Recommendations that can easily be implemented concern good-housekeeping practices, such as to blow leaves inwards and transport the leaves as solid waste instead of composting them. Granulates dispersed to paved surfaces, buildings and in drainage systems can be collected and disposed of as solid waste. In the recent years, new equipment has been developed to remove leaves by vacuuming. By immediate filtering, granulate falls back on the field whereas the leaves are contained in the machine.

To remove dirt that has already entered the infill layer and to reverse compaction, power brushing and raking are recommended 3-4 times per year [35]. In order to prevent dispersal of rubber granulate to the environment, collected residues should be considered as waste.

In case of snow clearance, it is recommended to store the snow in designated areas with paved surface and linings around. When the snow has been melted, granulate can either be reused on the fields or disposed of as solid waste. Common practice is to clear parts of the artificial turf area and when snow melts use regular maintenance machines to redistribute the infill over the cleared field. Many fields have dedicated, paved areas for snow clearance that are used in winter time or parts of the area for spectators are used. Although the snow piles are an unwelcome sight, they can be isolated from the natural environment.

The dispersal of granulate to the environment due to the cleaning of equipment can be completely prevented, if the cleaning is done on an (isolated) paved surface, that enables collection and recycling onto the fields or disposal of the granulate as solid waste.

The drainage system in the paved surfaces surrounding the artificial turf is designed to quickly move excess water to surface water or sewerage systems. Sinks are a constituent of a drainage systems and prevent clogging of the drainage tubes, with material that could precipitate, such as sand, rubber granulate or debris. The sinks not only protect against clogging, but also prevent the release of these materials to the surface water. These sinks need to be cleaned on a regular basis, and if rubber granulate is present the residue need to be disposed of as waste. The placement of filters in the drainage systems to capture microplastics has shown to be an effective measure; only $1 \mathrm{~kg}$ per field per year has been shown to pass the filter and reach the ditch [32].

\section{Discussion}

Far-reaching European wide policy to restrict ELT infill on sports field is proposed as part of a policy to reduce microplastics. In this paper we explained that rubber fill dispersal can be controlled and reduced to virtually zero. As a result, policy to ban rubber granulate will be ineffective to solve the microplastic issue and may even be counterproductive on another important issue such as the circular economy.

There are no scientific peer-reviewed publications about the fate and dispersal of ELT granulate used on outdoor artificial turf fields, and relevant grey studies have been published in foreign languages. This paper collected the grey literature, that contributes to the knowledge base by provision of measurements and experimental data. Studies were translated and used in the review to give an overview of the current state-ofknowledge with respect to ETL granulate dispersal. The fact that other sources (traffic related polymer particles, textile, microplastic pellets) are much more relevant was already mentioned in the introduction. The study of Regnell et al. [32] showed that even close to an artificial turf field, rubber infill comprised only a small fraction of the total microplastics present in drainage water, stormwater traps, and collecting wells (see Fig. 4).

The number of studies with measured data is small. We've found four studies that described monitoring results under outdoor conditions. The aims and the studies differed, which is reflected in the set-up and the accuracy and usefulness of the results. Aims varied from mass balance [40], environmental impact [37], infill loss by shoes [26], to efficacy of mitigation measures [32]. Sampling methods, analytical methods and reporting differ, which complicates comparison of the studies. Sampling methods differ in sample size, depth and/or distance to the field, most analyses have a physical nature, and chemical confirmation of the polymer has rarely been done. Reporting endpoints vary from number of particles to weight, volume or percentages. We have attempted to transform the outcomes of these studies to one uniform unit: $\mathrm{kg}$ infill dispersed to the environment per field per year. The dispersal of rubber granulate from artificial turf shows a huge variation. It appears that local conditions in field age, field maintenance, and geographical and meteorological conditions are the dominant factors. The studies that attempted to quantify the dispersal of ELT granulate and the annual infill demand were all 
conducted on fields that were constructed and maintained in a period when mitigation measures were not in practice, except for the study of Regnell [32]. Hence, the estimated quantities must be considered as to reflect a worst-case situation. Worst-case situations especially seem to occur by unawareness about granulate dispersal and the need and way how to mitigate microplastic dispersal. High infill demands, as estimated by Scandinavian sources, suggest that loss by snow clearance is particularly risky, while compaction as an in-field sink is ignored. It is striking that there are no measured data about the actual dispersal by snow. Only one Swedish study [38] estimated an ELT granulate removal of 20-30 L infill per snow removal occasion, based on interviews with caretakers. The representativity and reliability of this value cannot be assessed because the conditions (wet or dry) during snow clearance and the type of equipment have not been described.

One data seems to be particularly influential and that is the estimation of 3000-5000 kg of annual infill demand. This data traces back to 2009, although this original Danish source is not available. However, a similar reference from the same source of 2012 can be found [7]. Due to a lack of better data, this value has been adopted by many review studies, who extrapolated it to other countries and the EU as a whole $[18,20,22,24,36]$. Ultimately, this value still forms the basis of the ECHA restriction proposal.

The question can be raised if these Scandinavian values are representative for all countries within the European Union. Scandinavia belongs to a colder climate zone, whereas western and southern Europe belong to a more temperate climate zone with less snowfall [4]. With snow removal, a significant amount of rubber infill may be removed from the fields and, if not stored in a proper way, this may lead to environmental dispersal.

Snow removal is not common or not necessary in countries with temperate or warm climate. Data are only present from Scandinavia and The Netherlands. No studies have been found from Southern European countries. It makes sense that countries were infill dispersal is not (perceived as) an issue, have not invested into monitoring studies. Still it would be valuable if such data were collected, in order to differentiate the infill demand per country and to test the hypothesis that climate contributes to the infill demand.

Awareness about microplastic dispersal has risen in the past few years, which has led to adjustment of infrastructure, standard procedures for maintenances and rules for behavior of players. The annual refill demand can be reduced to $600-1200 \mathrm{~kg}$ per field, and is mainly needed to compensate for compaction on high-usage spots and to minor losses that can be collected as waste.
Besides the abovementioned recommendations and developments, the use of other infill materials or the construction of non-infill synthetic turf is under debate. A shift to common alternative infill materials like EPDM and TPE is not effective, because they are also considered microplastics. The use of natural infills may be considered, though they are usually only recommended for residential use because they are more susceptible to wear. Also, the availability, quality and certification of natural materials are more uncertain. Moreover, the light natural materials may float away during heavy rainfall. Finally, non-infill turfs consisting of fibers that are supported by smaller fibers may be considered. However, non-infill turf is more susceptible to increased wear and tear of the polyethylene fibers. While rubber granulate can be collected and reused, the worn fibers of a non-infill field are hard to collect and cannot be reused on the field. Because of their size and weight rubber particles tend to precipitate rapidly, in drainage sinks and sediment of nearby ditches. With frequent sweeping of paved surfaces and filters in the drainage system, the dispersal to ditch sediment can effectively be prevented [32]. The studies in this review indicate that dispersal of rubber granulate is a local issue, that can be minimized to virtually zero with the proper infrastructure and maintenance procedures.

\section{Conclusion}

This paper shows the current state-of-knowledge about ELT granulate dispersal and shows that approximately $600-1200 \mathrm{~kg}$ refill is required annually to compensate for compaction and for some infill waste on pavements and in drainage sinks. Recommended mitigation measures are containment through optimized field and drainage construction, suitable maintenance equipment and practices and good-housekeeping rules for players and groundkeepers and handling end-of-life pitches. If these recommendations are implemented, the emission of ELT granulates to the environment can be reduced to virtually zero.

\section{Supplementary Information}

The online version contains supplementary material available at https://doi. org/10.1186/s12302-021-00459-1.

Additional file 1. Quantification of rubber granules in soil and sediment.

Acknowledgements

The authors thank Swedish and Danish researchers for additional explanation of their published studies. 


\section{Authors' contributions}

AvG was involved in the set-up and critical reading of the manuscript. AJV wrote the first and final draft. AJV and UH were involved in some of the underlying experimental studies.

\section{Funding}

This work was funded by RecyBEM, the Dutch End-of-life Tyre Association.

\section{Availability of data and materials}

All data are publicly available through the internet.

Ethics approval and consent to participate

Not applicable.

\section{Consent for publication}

All authors approved the content of the manuscript.

\section{Competing interests}

The authors declare that they have no competing interests.

\section{Author details}

${ }^{1}$ De Milieutafel, Soest, The Netherlands. ${ }^{2}$ RecyBEM, The Hague, The Netherlands. ${ }^{3}$ SGS INTRON, Sittard, The Netherlands.

Received: 9 November 2020 Accepted: 23 January 2021

Published online: 05 March 2021

\section{References}

1. 1999/31/EC, Council Directive 1999/31/EC, of 16 April 1999 on the landfill of waste. Current consolidated version of 04 April 2018, https://eur-lex. europa.eu/legal-content/EN/TXT/?uri=CELEX:01999L0031-20180704. Accessed 28 July 2020

2. Bastin J-F, Finegold Y, Garcia C, Mollicone D, Rezende M, Routh D, Zohner CM, Crowther TW (2019) The global tree restoration potential. Science 365(6448):76. https://doi.org/10.1126/science.aax0848

3. Bauer B, Egebæk K, Aare AK (2017) Environmentally friendly substitute products for rubber granulates as infill for artificial turf fields. Norway: 42, https://www.miljodirektoratet.no/globalassets/publikasjoner/M955/ M955.pdf

4. Beck HE, Zimmermann NE, McVicar TR, Vergopolan N, Berg A, Wood EF (2018) Present and future Köppen-Geiger climate classification maps at 1-km resolution. Scientific Data 5(1):180214. https://doi.org/10.1038/ sdata.2018.214

5. BSNC (2019) Zorgplichtdocument milieu kunstgrasvelden. https://bsnc nl/wp-content/uploads/2020/01/BSNC-Rapport-Zorgplicht_Web_ def_150120.pdf.

6. CEN (2020) Surfaces for sports areas — synthetic turf sports facilitiesguidance on how to minimize infill dispersion into the environment. https://www.estc.info/wp-content/uploads/2020/03/FprCENTR-17519 -Public.pdf

7. DBU (2012) Gode råd om vedligehold af 3. Generations kunstgræs - fodboldbaner. Gode råd som supplement til kunstgræsbane leverandørernes garanti afhængige vedligeholdelsesvejledninger. (Danish Boldspil Union). https://docplayer.dk/1173936-Kunstgraes-fodboldbaner.html. Accessed 24 June 2020

8. ECHA (2017) Annex XV report. An evaluation of the possible health risks of recycled rubber granules used as infill in synthetic turf sports fields, $p$ 71

9. ECHA (2019) Annex XV restriction report. Proposal for a restriction. Substance name(s): intentionally added microplastics, version 1.2, 22 August 2019. Helsinki, ECHA. https://echa.europa.eu/nl/registry-of-restrictio n-intentions/-/dislist/details/0b0236e18244cd73

10. ECHA (2020a) RAC backs restricting intentional uses of microplastics, ECHA/NR/20/19. https://echa.europa.eu/-/rac-backs-restricting-inten tional-uses-of-microplastics.

11. ECHA (2020b) Restriction proposal on intentionally added microplastics_questions and answers. https://echa.europa.eu/docum ents/10162/28801697/qa_intentionally_added_microplastics_restrictio n_en.pdf/5f3caa33-c51f-869e-81c8-7e1852a4171c
12. ETRMA (2015) End-of-life Tyre report. https://www.etrma.org/library/endof-life-tyres-2015/

13. European Commission (2020) A new circular economy action plan for a cleaner and more competitive Europe, communication from the commission to the European parliament, the council, the European economic and social committee and the committee of the regions, COM/2020/98 final. https://eur-lex.europa.eu/legal-content/EN/ TXT/?uri=COM:2020:98:FIN

14. FIFA (2016) Laws of the game: 144. https://img.fifa.com/image/upload/ datdz0pms85gbnqy4j3k.pdf

15. Fleming PR, Forrester SE, McLaren NJ (2015) Understanding the effects of decompaction maintenance on the infill state and play performance of third-generation artificial grass pitches. In: Proceedings of the Institution of Mechanical Engineers. Part P, Journal of Sports Engineering and Technology 229(3): 169-182. doi: https://doi.org/10.1177/1754337114566480

16. Fleming PR, Watts C, Forrester SE (2020) A new model of third generation artificial turf degradation, maintenance interventions and benefits. In: Proceedings of the Institution of Mechanical Engineers. Part P, Journal of Sports Engineering and Technology. doi: https://doi.org/10.1177/17543 37120961602

17. Genan (2020) Maintenance of synthetic turf fields with rubber infill. Genan Inside, p 4. https://www.genan.us/wp-content/uploads/2020/02/ Maintenance-of-synthetic-turf-fields-with-rubber-infill-Genan-Inside.pdf

18. Hann S, Sherrington C, Jamieson O, Hickman M, Kershaw P, Bapasola A, Cole $\mathrm{G}$ (2018) Investigating options for reducing releases in the aquatic environment of microplastics emitted by (but not intentionally added in) products, Eunomia. https://ec.europa.eu/environment/marine/ good-environmental-status/descriptor-10/pdf/microplastics_final_repor t_v5_full.pdf

19. Hartmann N, Hüffer T, Thompson RC, Hassellöv M, Verschoor A, Daugaard AE, Rist S, Karlsson T, Brennholt N, Cole M, Herrling MP, Hess MC, Ivleva NP, Lusher AL, Wagner M (2019) Are we speaking the same language? Recommendations for a definition and categorization framework for plastic debris. Environ Sci Technol 53(3):1039-1047. https://doi.org/10.1021/acs. est.8b05297

20. Kjær KB (2013) Miljø- og sundhedsskadelige stoffer i drænvand fra kunstgræsbaner. Oversigt over eksisterende analyseresultater på danske kunstgræsbaner samt supplerende måleprogram på to udvalgte baner, DHI: 96. http://regnvandskvalitet-abc.teknologisk.dk/media/1037/miljo e-og-sundhedsskadelige-stoffer-i-draenvand-fra-kunstgraesbaner.pdf

21. Kreider ML, Panko JM, McAtee BL, Sweet LI, Finley BL (2010) Physical and chemical characterization of tire-related particles: comparison of particles generated using different methodologies. Sci Total Environ 408(3):652659. https://doi.org/10.1016/j.scitotenv.2009.10.016

22. Lassen C, Foss-Hansen S, Magnusson K, Norén N, Hartmann NI, RehneJensen P, NTG, Brinch A (2015) Microplastics. Occurrence, effects and sources of releases to the environment in Denmark, Danish EPA: 208. https://orbit.dtu.dk/files/118180844/Lassen_et_al._2015.pdf

23. Løkkegaard H, Malmgren-Hansen B, Nilsson NH (2018) Mass balance of rubber granulate lost from artificial turf fields, focusing on discharge to the aquatic environment. A review of literature. (Revised May 2019), DTI: 25. https://www.genan.eu/wp-content/uploads/2020/02/Teknologis k-Institut Mass-balance-of-rubber-granulate-lost-from-artificial-turf-field s_May-2019_v1.pdf

24. Magnusson $\mathrm{K}$, Eliasson $\mathrm{K}$, Fråne $\mathrm{A}$, Haikonen $\mathrm{K}$, Hultén J, Olshammar M, Stadmark J, Voisin A (2016) Swedish sources and pathways for microplastics to the marine environment. A review of existing data. (revised version 2017), IVL: 89. https://www.ccb.se/documents/ML_background/SE_Study MP_sources.pdf

25. Merlin B, Vogt R (2020) Life cycle assessment of waste tyre treatments: material recycling vs. coincineration in cement kilns. Project no. 11831036 commissioned by Genan Holding A/S.: 93

26. Norges forskningsråd (2017) Sjekk kunstgressbanen. FORSKNINGSKAMPANJEN 2017. Rapport fra undersøkelser om svinn av gummigranulat fra kunstgressbaner, gjennomført av over 12000 elever og spillere høsten 2017 (Check the artificial turf path. THE RESEARCH CAMPAIGN 2017. Report from surveys on waste of rubber granules from artificial turf, conducted by over 12,000 students and players in the fall of 2017). Norway: 19. https://www.miljolare.no/innsendt/oppslag/1486/5af04d407fd75/ rapport_forskningskampanjen_2017.pdf 
27. Oliveri-Conti G, Ferrante M, Banni M, Favara C, Nicolosi I, Cristaldi A, Fiore M, Zuccarello P (2020) Micro- and nano-plastics in edible fruit and vegetables. The first diet risks assessment for the general population. Environ Res 187:109677. https://doi.org/10.1016/j.envres.2020.109677

28. OSPAR (2017) Assessment document of land-based inputs of microplastics in the marine environment, p 94. www.ospar.org/docum ents? $=38018$

29. Pronk MEJ, Woutersen M, Herremans JMM (2010) Synthetic turf pitches with rubber granulate infill: are there health risks for people playing sports on such pitches?" J Exposure Sci Environ Epidemiol 30(3):567-584

30. RecyBEM (2015) Ecotest infill material, comparison different infill materials in relation to PAH restriction Regulation(EU) 1272/2013, 15p.

31. Redondo-Hasselerharm PE, de Ruijter VN, Mintenig SM, Verschoor A, Koelmans AA (2018) Ingestion and chronic effects of car tire tread particles on freshwater benthic macroinvertebrates. Environ Sci Technol 52(23):13986-13994. https://doi.org/10.1021/acs.est.8b05035

32. Regnell $F$ (2019) Dispersal of microplastic from a modern artificial turf pitch with preventive measures_case study Bergaviks IP, Kalmar, Ecoloop: 27. https://www.genan.eu/wp-content/uploads/2020/02/MPdispersal-from-Bergavik-IP-Kalmar-Report.pdf

33. SAPEA (2019) A scientific perspective on microplastics in nature and society. Berlin. https://www.sapea.info/topics/microplastics/

34. Schneider K, Bierwisch A, Kaiser E (2020) ERASSTRI - European risk assessment study on synthetic turf rubber infill—part 3: exposure and risk characterisation. Sci Total Environ 718:137721. https://doi.org/10.1016/j. scitotenv.2020.137721

35. Sharma P, Fleming P, Forrester S, Gunn J (2016) Maintenance of artificial turf-putting research into practice. Procedia Eng 147:830-835. https:// doi.org/10.1016/j.proeng.2016.06.298
36. Sundt P, Syversen F, Skogesal O, Schulze PE (2016) Primary microplastic pollution: measures and reduction potentials in Norway, Mepex, p 117. https://holdnorgerent.no/wp-content/uploads/2016/10/Primary-micro -plastic-pollution_Measures-and-reduction-potentials-in-Norway.pdf

37. Verschoor AJ, Bodar CWM, Baumann RA (2018) Verkenning milieueffecten rubbergranulaat bij kunstgrasvelden (The environmental impact of rubber infill near synthetic turf fields). The Netherlands, RIVM, p 112. https:// www.rivm.nl/bibliotheek/rapporten/2018-0072.pdf

38. Wallberg (2016) Dackmaterial i konstgräsplaner: 44. https://www.sdab.se/ media/1120/daeckmaterial_i_konstgraesplaner.pdf

39. WBCSD (2019) Global ELT management - a global state of knowledge on regulation, management systems, impacts of recovery and technologies, p 57. https://www.wbcsd.org/Sector-Projects/Tire-Industry-Project/Endof-Life-Tires-ELTs

40. Weijer A, Knol J, Hofstra U (2017) Verspreiding van infill en indicatieve massabalans, SWECO, SGS Intron: 48. https://www.bsnc.nl/wp-conte nt/uploads/2017/05/Rapportage-Verspreiding-van-infill-en-indicatiev e-massabalans.pdf

41. Zitouni N, Bousserrhine N, Belbekhouche S, Missawi O, Alphonse V, Boughatass I, Banni M (2020) First report on the presence of small microplastics $(\leq 3 \mu \mathrm{m})$ in tissue of the commercial fish Serranus scriba (Linnaeus. 1758) from Tunisian coasts and associated cellular alterations. Environ Pollut 263:1 14576. https://doi.org/10.1016/j.envpol.2020.114576

\section{Publisher's Note}

Springer Nature remains neutral with regard to jurisdictional claims in published maps and institutional affiliations.

\section{Submit your manuscript to a SpringerOpen ${ }^{\circ}$ journal and benefit from:}

- Convenient online submission

- Rigorous peer review

- Open access: articles freely available online

- High visibility within the field

- Retaining the copyright to your article

Submit your next manuscript at $\boldsymbol{\nabla}$ springeropen.com 